\title{
Population-based study of acquired cerebellar ataxia in Al-Kharga district, New Valley, Egypt
}

\author{
This article was published in the following Dove Press journal: \\ Neuropsychiatric Disease and Treatment \\ 4 April 20II \\ Number of times this article has been viewed
}

\author{
Wafaa MA Farghaly' \\ Hamdy N El-Tallawy' \\ Ghaydaa A Shehata' \\ Tarek A Rageh' \\ Nabil Abdel Hakeem² \\ Noha M Abo-Elfetoh' \\ 'Department of Neurology and \\ Psychiatry, Assiut University, \\ Assiut, Egypt; ${ }^{2}$ Al Azhar University, \\ Assiut Branch, Egypt
}

Background: The aim of this research was to determine the prevalence and etiology of acquired ataxia in Al-Kharga district, New Valley, Egypt.

Methods: A population-based study of acquired ataxia was conducted in a defined geographical region with a total population of 62,583. A door-to-door survey was used to identify cases of acquired cerebellar ataxia. Patients with acquired cerebellar ataxia at any age and of both genders were included. Cases of known inherited cerebellar ataxia, acquired neurological disorders with ataxia as a minor feature, or pure acquired sensory ataxia, were excluded.

Results: We identified 17 cases of acquired ataxia, of which eight were vascular, six were an ataxic cerebral palsy subtype, and three involved postencephalitic ataxia. The crude prevalence rate for acquired ataxia was 27.16/100,000 (95\% confidence interval [CI]: 14.3-40.1). The mean age of the patients at interview was 31.8 (range 4-72) years, with a male to female ratio of 2.1:1. The most frequent presenting complaint was disturbance of gait $(90.7 \%)$. The majority $(92 \%)$ were ambulatory, but only $9.3 \%$ were independently self-caring.

Conclusion: This population-based study provides an insight into acquired cerebellar ataxia within a defined region, and may inform decisions about the rational use of health care resources for patients with acquired cerebellar ataxia. The most common causes of acquired cerebellar ataxia in this region were cerebrovascular injury and cerebral palsy.

Keywords: acquired cerebellar ataxia, prevalence, subtypes, Egypt

\section{Introduction}

The ataxias are a clinically, pathologically, and etiologically heterogeneous group of disorders that result in a considerable health burden., ${ }^{1,2}$ The widely variable and overlapping symptoms and signs, often with additional extracerebellar involvement, complicate the clinical assessment. ${ }^{1}$ There are many diseases that may lead to ataxia. Determining the cause of ataxia may be very difficult, and requires a careful series of steps planned by an experienced physician. ${ }^{3}$ Often the diagnosis cannot be made immediately, but requires careful examination and follow-up for the progression or resolution of symptoms over time. ${ }^{4}$

According to current etiology-based classifications, the ataxias can be subdivided into three major groups, ie, acquired ataxias with exogenous or endogenous nongenetic causes, hereditary ataxias, and nonhereditary degenerative ataxias. ${ }^{5}$

A wide range of potential causes of acquired ataxia has been identified. ${ }^{6}$ These causes include disorders in which ataxia is a prominent sign, such as vascular ataxia, alcohol-induced cerebellar degeneration, ataxia due to other toxic causes, paraneoplastic cerebellar degeneration, other immune-mediated ataxias, and ataxia in chronic central nervous system infection, as well as metabolic encephalopathies
Correspondence: Ghaydaa A Shehata Department of Neurology and Psychiatry, Assiut University, PO Box 7I516, Assiut, Egypt Tel +2 0882297075

Fax +2 0882333327

Email ghaydaa83@yahoo.com 
and endocrine disorders in which ataxia is part of a more complex syndrome..$^{5-8}$

Approximately 150,000 people in the US alone are affected by ataxia, either the acquired or hereditary form, with a lifetime prevalence rate of 50/100,000. ${ }^{1}$ Previously reported estimates from isolated and selected populations have yielded a prevalence for hereditary ataxias of $0.31-41 / 100,000 .^{5}$

\section{Patients and methods}

This was a community-based study, carried out in the Al-Kharga district, New Valley, Egypt. The New Valley represents about $40 \%$ of Egypt's total land area. It is divided into three oases, ie, the Al-Kharga (capital), Al-Farafra, and Al-Dakhla districts. The investigators chose this area because it is far away from the Nile Valley, with different geographical, social, economic, and cultural characteristics, as well as a high rate of genetic diseases, and is considered to be a closed area and a homogeneous entity.

Informed consent was obtained from all subjects included in this study or from the responsible person in each family or health institute. The regional ethics committee of Assiut University Hospital approved the study.

The total population was 62,583 . The distribution of the sample was 44,600 (71.3\%) subjects from urban and 17,983 (29.7\%) from rural areas. This study was a part of a wider project designed to detect major neurological disorders in the Al-Kharga district, and was multistaged. The first stage was carried out by screening all the population in the Al-Kharga district using a door-to-door survey by neurologists administering a reliable and valid Arabic screening scale prepared specifically for this study. ${ }^{9}$ Suspected cases were then referred to Assiut University Hospital for case ascertainment and independent investigations by six neurologists. Each patient underwent magnetic resonance imaging and metabolic screening as necessary.

Cerebellar ataxias were defined and classified according to clinical presentation, mode of onset, etiology, and inheritance. ${ }^{10}$ The diagnosis was based on the person's medical history, family history, and complete neurological evaluation, including a brain magnetic resonance scan. All cases with acquired cerebellar ataxia at any age and of both genders were included. In epidemiology, the term "prevalence" of cerebellar ataxia usually refers to the estimated population of people who have the disease at the time of the study, starting at any point during their lives. Cerebellar ataxias are rare, and the prevalence rate is estimated in numbers per $100,000 .{ }^{8}$

A total of 24 patients with cerebellar ataxia were recorded in our previous study, ${ }^{11}$ with a prevalence rate of $38.34 / 100,000$ (CI: 23.01-53.69). Of these cases, 17 patients (70.8\%) had acquired (noninherited) cerebellar ataxia. The lifetime prevalence rate was $27.16 / 100,000$ (95\% CI: $14.3-40.1)$. Seven patients $(29.2 \%)$ had inherited cerebellar ataxia, with a lifetime prevalence rate of 11.19/100,000 (95\% CI: 2.90-19.47). In this study, patients with acquired cerebellar ataxia were included. Clinical data for these patients were described. In addition, the affected population was classified according to the method described by Nichols et al ${ }^{12}$ ie, into childhood (0-18 years), adulthood (18-40 years), middle age (40-60 years), and elderly ( $>60$ years).

Vascular cerebellar ataxia was diagnosed on the basis of a history suggestive of vascular origin, eg, infarction or hemorrhage. ${ }^{13}$ Ataxic cerebral palsy was diagnosed according to the criteria of Andersen et al. ${ }^{14}$ Postencephalitic ataxia was diagnosed on the basis of a suggestive history of encephalitis confirmed by a medical report from a doctor or hospital prior to the onset of cerebellar ataxia (with electrocardiographic and/or serological findings).

\section{Statistical methods}

The Statistical Package for Social Sciences (SPSS) for Windows (version 12.0.1; SPSS Inc, Chicago, IL) and EpiCalc 2000 EpiCalc (v 1.02; Brixton Health, Llanidloes, UK) were used for the data analysis. The Chi-square test, independentsamples $t$-test, and one-way analysis of variance test followed by the post hoc test (least squares difference) were used to analyze differences in proportions between the groups. The 95\% CI for prevalence was calculated using Excel. Odds ratios and $95 \%$ CIs were used to compare gender (male and female) and residence (urban and rural) by Chi-square. A statistical significance level of 0.05 was chosen.

\section{Results}

Demographic, clinical, and radiological data for the 17 patients with acquired cerebellar ataxia are shown in Table 1 and

Table I Demographic characteristics of 17 patients identified as having acquired cerebellar ataxia

\begin{tabular}{ll}
\hline Variables & Patient data \\
\hline Mean (range) age of patients at interview (years) & $31.8($ range 4-72) \\
Gender (n, \%) & $10(58.8 \%)$ \\
Males & $7(41.2 \%)$ \\
Females & \\
Level of education (n, \%) & $3(17.6 \%)$ \\
Preschool age & $9(52.9 \%)$ \\
Read and write & $2(11.8 \%)$ \\
Six years of education & $2(11.8 \%)$ \\
Nine years of education & $1(5.9 \%)$ \\
University & $62(1-264)$ \\
Mean duration of illness in months (range)
\end{tabular}


Table 2 Clinical and radiological finding in patients with acquired ataxia

\begin{tabular}{|c|c|c|c|c|}
\hline $\begin{array}{l}\text { Patient number/age } \\
\text { (years)/gender }\end{array}$ & Classify group & Cerebellar finding & Extra-cerebellar finding & MRI finding \\
\hline $\mathrm{I} / \mathrm{I} 3.0 / \mathrm{M}$ & Ataxic cerebral palsy & $\begin{array}{l}\text { Tremor, incoordination, } \\
\text { ataxic gait }\end{array}$ & $\begin{array}{l}\text { Bilateral pyramidal and } \\
\text { GTC seizure }\end{array}$ & White matter changes \\
\hline 2/6.0/M & Ataxic cerebral palsy & $\begin{array}{l}\text { Tremor, incoordination, } \\
\text { ataxic gait }\end{array}$ & Bilateral pyramidal & White matter changes \\
\hline 3/7.0/M & Ataxic cerebral palsy & $\begin{array}{l}\text { Tremor, incoordination, } \\
\text { ataxic gait }\end{array}$ & Bilateral pyramidal & White matter changes \\
\hline 4/6.0/M & Ataxic cerebral palsy & Tremor and incoordination & - & White matter changes \\
\hline $5 / 4.0 / M$ & Postencephalitic & $\begin{array}{l}\text { Tremor, incoordination, } \\
\text { ataxic dysarthria }\end{array}$ & Choreathetosis, dystonia & $\begin{array}{l}\text { Postencephalitic } \\
\text { hypodense area }\end{array}$ \\
\hline 6/I2.0/F & Ataxic cerebral palsy & $\begin{array}{l}\text { Tremor, incoordination, } \\
\text { ataxic gait }\end{array}$ & - & White matter changes \\
\hline $7 / 11.0 / F$ & Ataxic cerebral palsy & $\begin{array}{l}\text { Tremor, incoordination, } \\
\text { ataxic gait }\end{array}$ & Bilateral pyramidal & Atrophic changes \\
\hline $8 / 61.0 / \mathrm{M}$ & Vascular & $\begin{array}{l}\text { Tremor, incoordination, } \\
\text { cerebellar ataxic gait }\end{array}$ & Bilateral pyramidal & Cerebellar infarction \\
\hline 9/20.0/M & Post-encephalitic & $\begin{array}{l}\text { Tremor, incoordination, } \\
\text { ataxic dysarthria }\end{array}$ & $\begin{array}{l}\text { Bilateral pyramidal, } \\
\text { extrapyramidal, GTC seizure }\end{array}$ & $\begin{array}{l}\text { Postencephalitic } \\
\text { hypodense areas }\end{array}$ \\
\hline $10 / 51.0 / M$ & Vascular & $\begin{array}{l}\text { Tremor, incoordination, } \\
\text { ataxic gait }\end{array}$ & Bilateral pyramidal & $\begin{array}{l}\text { Cerebellar and capsular } \\
\text { infarction }\end{array}$ \\
\hline $\mathrm{II} / 70.0 / \mathrm{M}$ & Vascular & $\begin{array}{l}\text { Tremor, incoordination, } \\
\text { ataxic gait }\end{array}$ & Bilateral pyramidal & Cerebellar infarction \\
\hline $12 / 33.0 / M$ & Vascular & Tremor, incoordination & $\begin{array}{l}\text { Bilateral pyramidal, } \\
\text { GTC seizure }\end{array}$ & $\begin{array}{l}\text { Cerebellar, capsular, } \\
\text { and cortical infarction }\end{array}$ \\
\hline $13 / 28.0 / F$ & Postencephalitic & $\begin{array}{l}\text { Tremor, incoordination, } \\
\text { ataxic gait }\end{array}$ & $\begin{array}{l}\text { Bilateral pyramidal, } \\
\text { behavioral changes }\end{array}$ & $\begin{array}{l}\text { Postencephalitic } \\
\text { hypodense area }\end{array}$ \\
\hline |4/73.0/F & Vascular & $\begin{array}{l}\text { Tremor, incoordination, } \\
\text { ataxic gait }\end{array}$ & Bilateral pyramidal & infarction Cerebellar \\
\hline I5/65.0/F & Vascular & $\begin{array}{l}\text { Tremor, incoordination, } \\
\text { ataxic gait }\end{array}$ & Bilateral pyramidal & $\begin{array}{l}\text { Cerebellar and } \\
\text { capsular infarction }\end{array}$ \\
\hline $16 / 62.0 / F$ & Vascular & $\begin{array}{l}\text { Tremor, incoordination, } \\
\text { ataxic gait }\end{array}$ & Bilateral pyramidal & Hemorrhage \\
\hline 17/63.0/F & Vascular & $\begin{array}{l}\text { Tremor, incoordination, } \\
\text { ataxic gait }\end{array}$ & Bilateral pyramidal & Hemorrhage \\
\hline
\end{tabular}

Abbreviations: MRI, magnetic resonance image; GTC, generalized tonic colonic seizures; M, male; F, female.

Table 2. The mean age of the patients at interview was 31.8 (range 4-72) years. The mean duration of illness was 62.1 (range 1-264) months. The 17 patients with cerebellar ataxia $(70.8 \%)$ had acquired (noninherited) ataxia, with a lifetime prevalence rate of 27.16/100,000 (95\% CI: 14.3-40.1). Acquired ataxia was classified into vascular ataxia, ataxic cerebral palsy, and postencephalitic ataxia. No cases of cerebellar ataxia relating to trauma, multiple sclerosis, or tumors were recorded. There was no statistically significant difference between males and females with regard to the prevalence rate/ 100,000 of cerebellar ataxia and its subtypes (Table 3 ) in the community.

Table 4 shows the age-specific prevalence rate of different types of acquired cerebellar ataxia. The only type recorded in the elderly group ( $>60$ years) was vascular cerebellar ataxia, with a prevalence rate of $124.4 / 100,000$.

\section{Discussion}

Many patients have progressive ataxia which can result from environmental insults and other well recognized disorders involving the nervous system. Here we describe the prevalence rate of acquired cerebellar ataxia in a defined geographical area. In any patient presenting with cerebellar ataxia, disorders such as ischemic or hemorrhagic stroke involving the cerebellum, previous episodes of cerebral hypoxia, primary or postinfectious sequelae, and demyelinating diseases, such as multiple sclerosis, can be diagnosed by appropriate history, imaging studies, and other investigations. ${ }^{15}$ Many of these diseases tend to have an acute or subacute evolution rather than the chronic course associated with the degenerative ataxias. However, there are diseases that can present with ataxia, in which the major imaging abnormality may be an atrophic cerebellum similar to that found for the degenerative ataxias. 
Table 3 Gender- and residence-specific prevalence rate of acquired cerebellar ataxia and its subtypes

\begin{tabular}{|c|c|c|c|c|c|c|c|}
\hline & $\begin{array}{l}\text { Total } \\
(n=62,583) \\
(\text { prevalence } / 100,000) \mathrm{Cl}\end{array}$ & $\begin{array}{l}\text { Male } \\
(n=32,165)\end{array}$ & $\begin{array}{l}\text { Females } \\
(n=30,4 \mid 8)\end{array}$ & $P$-value & $\begin{array}{l}\text { Urban } \\
(n=44,600)\end{array}$ & $\begin{array}{l}\text { Rural } \\
(n=17,983)\end{array}$ & $P$-value \\
\hline Acquired ataxia & $\begin{array}{l}17(27.16) \\
14.3-40.1\end{array}$ & $10(31.1)$ & 7 (23.0I) & 0.356 & $12(26.91)$ & $5(27.80)$ & 0.418 \\
\hline Vascular ataxia & $\begin{array}{l}8(12.78), \\
3.93-21.64\end{array}$ & $4(12.44)$ & $4(13.15)$ & 0.606 & $6(13.45)$ & $2(11.12)$ & 0.584 \\
\hline $\begin{array}{l}\text { Postencephaltic } \\
\text { ataxia }\end{array}$ & $\begin{array}{l}3 \text { (4.79), } \\
0.63-10.22\end{array}$ & $2(6.22)$ & I (3.29) & 0.521 & $2(4.48)$ & I (5.56) & 0.632 \\
\hline $\begin{array}{l}\text { Ataxic cerebral } \\
\text { palsy }\end{array}$ & $\begin{array}{l}6 \text { (9.59), } \\
1.92-17.26\end{array}$ & $4(12.44)$ & $2(6.58)$ & $0.37 \mid$ & $4(8.97)$ & $2(11.13)$ & 0.552 \\
\hline
\end{tabular}

Notes: $P$-value $<0.05$ at exact significance (one-sided); Values were given as a number (prevalence was calculated per 100,000); A Monte Carlo confidence level of 95\% was used.

The most common presenting symptoms in our patients were tremors, impairment of coordination, ataxic dysarthria, and ataxic gait. In addition, many patients had extracerebellar symptoms, including bilateral pyramidal and extrapyramidal manifestations. Few studies have reported the clinical features of ataxia, but have been discussed by Matthews et al. ${ }^{16}$ Some patients were described as having ataxic dysarthria with an ataxic gait and dysmetric finger-to-nose-to-finger and heel-to-shin testing. ${ }^{16}$

The prevalence of acquired (noninherited) cerebellar ataxia in this study was 27.16/100,000 (95\% CI: 14.3-40.1), which is higher than that reported in 2004 for South East Wales in the UK $(8.4 / 100,000,95 \%$ CI: $7.2-11.6) .{ }^{17}$ This difference could be attributed to the different age groups of the populations studied. Whereas the UK study was restricted to late-onset acquired ataxia ( $>18$ years) only, we included a broader age range (4-73 years) in our study. Our results demonstrated that there were no statistically significant differences between males and females with regard to lifetime prevalence for acquired cerebellar ataxia or its subtypes.

In this study, the most common type of acquired cerebellar ataxia was the vascular type, with a prevalence rate of $12.78 / 100,000$, and was the only type recorded in elderly individuals. This could be explained by the increased prevalence of stroke in this age group, given that the chance of having a stroke approximately doubles for each decade of life after the age of 55 years. ${ }^{13}$
The second type was ataxic cerebral palsy, with a prevalence rate of 9.59/100,000 and this was the main presenting type in children. Ataxic cerebral palsy is one of the leading causes of childhood disability worldwide, with the greatest burden found in developing countries like India. Therefore, thorough evaluation of all children with cerebral palsy is essential to enable appropriate rehabilitation. ${ }^{18}$

Ataxia can be one of the features of postinfectious encephalomyelitis, but usually accompanies a more diffuse cerebral process. ${ }^{15}$ In our study, only three cases were diagnosed as postencephalitic cerebellar ataxia. This may be related to a lack of recorded information and hospital registration. A more limited cerebellar syndrome has been seen in children after a viral infection. It has been proposed that this diagnosis should be considered when children develop an acute ataxic disorder that is not associated with a more diffuse process, ie, seizures, meningismus, or obtundation. In most children, this was preceded by a nonspecific viral infection or varicella, with a peak incidence at 5-6 years of age. In our study, we did not find any cases of post-traumatic ataxia, or any cases associated with paraneoplasm, multiple sclerosis, or alcoholism. With regard to the latter, alcohol is traditionally forbidden according to the religion of the Egyptian people.

\section{Conclusion}

The prevalence rate of acquired cerebellar ataxia was 27.2/100,000 in the Al-Kharga district, New Valley, Egypt.

Table 4 Age-specific prevalence rate of acquired cerebellar ataxia

\begin{tabular}{|c|c|c|c|c|c|}
\hline & $\begin{array}{l}\text { Childhood } \\
(n=25,539)\end{array}$ & $\begin{array}{l}\text { Adulthood } \\
(n=23,070)\end{array}$ & $\begin{array}{l}\text { Middle-aged } \\
(\mathrm{n}=10,758)\end{array}$ & $\begin{array}{l}\text { Elderly } \\
(n=3,216)\end{array}$ & $P$-value \\
\hline $\begin{array}{l}\text { Acquired (noninherited) } \\
\text { cerebellar ataxia }\end{array}$ & $7(27.4 I)$ & $3(13.0)$ & $3(27.89)$ & $4(124.38)$ & 0.082 \\
\hline Vascular ataxia & 0 & I (4.33) & $3(27.9)$ & $4(124.38)$ & $0.000^{*}$ \\
\hline Postencephalitic ataxia & I (3.92) & $2(8.67)$ & 0 & 0 & 0.692 \\
\hline Ataxic cerebral palsy & $6(23.50)$ & 0 & 0 & 0 & $0.015^{*}$ \\
\hline
\end{tabular}

Notes: Values were given as number (prevalence were calculated per 100,000); We compared different age groups by proportions as a trend using EpiCalc 2000. *significant at an alpha level of 0.05 . 
The prevalence, in descending order, was vascular ataxia, followed by ataxic cerebral palsy, and postencephalitic ataxia.

\section{Disclosure}

The authors report no conflicts of interest in this work.

\section{References}

1. Harding AE, Diengdoh JV, Lees AJ. Autosomal recessive late onset multisystem disorder with cerebellar cortical atrophy at necropsy: Report of a family. J Neurol Neurosurg Psychiatry. 1984;47(8):853-856.

2. Klockgether T. Recent advances in degenerative ataxias. Curr Opin Neurol. 2000;13(4):451-455.

3. Miyoshi Y, Yamada T, Tanimura M, et al. A novel autosomal dominant spinocerebellar ataxia (SCA16) linked to chromosome 8q22.1-24.1. Neurology. 2001;57(1):96-100.

4. Koide R, Kobayashi S, Shimohata T, et al. A neurological disease caused by an expanded CAG trinucleotide repeat in the TATA-binding protein gene: A new polyglutamine disease? Hum Mol Genet. 1999; 8(11):2047-2053.

5. Klockgether T. Sporadic ataxia with adult onset: Classification and diagnostic criteria. Lancet Neurol. 2010;9(1):94-104.

6. Fogel BL, Perlman S. An approach to the patient with late-onset cerebellar ataxia. Nat Clin Pract Neurol. 2006;2(11):629-635.

7. Muzaimi MB, Thomas J, Palmer-Smith S, et al. Population based study of late onset cerebellar ataxia in South East Wales. J Neurol Neurosurg Psychiatry. 2004;75(8):1129-1134.

8. Nakamura K, Jeong SY, Uchihara T, et al. SCA17, a novel autosomal dominant cerebellar ataxia caused by an expanded polyglutamine in TATA-binding protein. Hum Mol Genet. 2001;10(14):1441-1448.
9. Tallawy HE, Farghaly W, Metwaly NA, et al. Door-to-door survey of major neurological disorders in A1 Kharga District, New Valley, Egypt: Methodological aspects. Neuroepidemiology. 2010;35:185-190.

10. Fujigasaki H, Martin JJ, De Deyn PP, et al. CAG repeat expansion in the TATA box-binding protein gene causes autosomal dominant cerebellar ataxia. Brain. 2001;124(Pt 10):1939-1947.

11. Farghaly W, Tallawy HE, Rageh T, Shehata G, Metwaly N, Elfetoh NA. Epidemiology of cerebellar ataxia in Al-Kharga District-New Valley (Egypt). Egypt J Neurol Psychiatr Neurosurg. 2010;47(3):527-532.

12. Nichols BR, Hentz KL, Aylward L, Hays SM, Lamb JC. Age-specific reference ranges for polychlorinated biphenyls (PCB) based on the NHANES 2001-2002 survey. J Toxicol Environ Health A. 2007;70(21): 1873-1877.

13. Min WK, Kim YS, Kim JY, Park SP, Suh CK. Atherothrombotic cerebellar infarction: Vascular lesion-MRI correlation of 31 cases. Stroke. 1999;30(11):2376-2381.

14. Andersen GL, Irgens LM, Haagaas I, Skranes JS, Meberg AE, Vik T. Cerebral palsy in Norway: Prevalence, subtypes and severity. Eur $J$ Paediatr Neurol. 2008;12(1):4-13.

15. Subramony SH. In: Bradley WG, editor. Neurology in Clinical Practice. 5th ed. Philadelphia, PA: Butterworth-Heinemann/Elsevier; 2008.

16. Matthews BR, Jones LK, Saad DA, Aksamit AJ, Josephs KA. Cerebellar ataxia and central nervous system Whipple disease. Arch Neurol. 2005; 62(4):618-620.

17. Tallaksen CM. Hereditary ataxias. Tidsskr Nor Laegeforen. 2008; 28(17):1977-1980. Norwegian.

18. Bhatia M, Joseph B. Rehabilitation of cerebral palsy in a developing country: The need for comprehensive assessment. Pediatr Rehabil. 2000;4(2):83-86.
Neuropsychiatric Disease and Treatment

\section{Publish your work in this journal}

Neuropsychiatric Disease and Treatment is an international, peerreviewed journal of clinical therapeutics and pharmacology focusing on concise rapid reporting of clinical or pre-clinical studies on a range of neuropsychiatric and neurological disorders. This journal is indexed on PubMed Central, the 'PsycINFO' database and CAS, and is the official

\section{Dovepress}

journal of The International Neuropsychiatric Association (INA). The manuscript management system is completely online and includes a very quick and fair peer-review system, which is all easy to use. Visit http://www.dovepress.com/testimonials.php to read real quotes from published authors. 